\title{
Foreword
}

\section{Hematopoietic stem cell transplantation in pediatric critical care}

\author{
Robert F. Tamburro* \\ Department of Pediatric Trauma and Critical Illness Branch, Eunice Kennedy Shriver National Institute of Child \\ Health and Human Development, Rockville, MD, USA
}

Received 27 September 2014

Accepted 27 September 2014

Hematopoietic stem cell transplantation (HSCT) offers hope as a potential curative therapy for a number of life-threatening malignant and non-malignant disease processes. Recent data suggest that over 2500 children undergo HSCT each year as a potential cure for leukemia, lymphoma and other malignant diseases as well as for a host of other disease processes including immuno-deficiencies, metabolic disorders, bone marrow failure syndromes, hemoglobinopathies and rheumatologic conditions [1].

However, HSCT can be associated with a variety of complications and significant morbidity. Recent data suggest that approximately one third of pediatric HSCT recipients will require admission to the pediatric intensive care unit [2]. Thus, for HSCT to continue to expand in both terms of success and breadth of application, effective supportive care to treat these complications and minimize morbidity is essential. A sound understanding of the pathophysiology associated with the unique morbidities of the HSCT process as well as the unusual courses of common complications is needed. Clearly, HSCT patients have worse outcomes for most organ failures than the general pediatric population requiring critical care services including the non-transplant oncology patients [3-5].

*Corresponding author: Dr. Robert F. Tamburro, Medical Officer, Pediatric Trauma and Critical Illness Branch Program Officer, Pediatric Critical Care Program, Eunice Kennedy Shriver National Institute of Child Health and Human Development, 6100 Executive Blvd Room 8B07K, Rockville, MD, USA. E-mail: robert.tamburro@nih.gov.
Encouragingly, outcomes appear to be improving for these children. For example, survival among pediatric HSCT patients requiring mechanical ventilation for lung injury has improved from approximately $10 \%$ in the early 1990s [6] to rates approximating 50\% or better in some recent series [7-9]. Reduced intensity conditioning regimens, improved supportive care, and more aggressive antimicrobial prophylaxis have all been suggested as reasons for the improvement. In conjunction with these improved outcomes, research interest in this patient population appears to be growing. Once excluded from clinical trials because of overwhelmingly poor outcomes, these patients have now become accepted subjects in many such studies $[10,11]$. Multicenter clinical trials specifically targeting pulmonary complications of the HSCT process are now being conducted $[12,13]$. Moreover, therapies once not offered to this patient population because of an unfavorable risk-benefit balance, are now being offered with increasing frequency. For example, reports of the use of extracorporeal membrane oxygenation for the pediatric HSCT patient can now be found speckling the published literature and respective patient registries $[14,15]$. The philosophic approach to critical illness in this patient population appears to be changing from one of futility and frustration to one of potential and promise.

In this special edition of the Journal of Pediatric Intensive Care, a historical perspective of the care and outcomes of the critically ill HSCT patient is presented to provide both a context of the recent advancements in the field and a foundation for further study. 
For outcomes to continue to improve, pediatric critical care medicine providers must work closely and collegially with their transplant colleagues in a multidisciplinary fashion that includes physicians, nurses, therapists, pharmacists, social workers and all other members of the health care team. They must strive to attain a basic understanding of the HSCT process and the underlying principles. In this edition, the basics of the HSCT process are described by a group of HSCT physicians to facilitate such an understanding among critical care providers. Moreover, pediatric critical care clinicians must possess a sound understanding of the complications and co-morbidities of the HSCT process that require their services. Manuscripts included in this special edition describe unique complications of HSCT including graft versus host disease and sinusoidal obstruction syndrome (formerly known as veno-occlusive disease); two life-threatening complications of this therapy. Graft versus host disease is the most frequent and serious complication following allogeneic HSCT occurring in approximately one fifth of these children admitted to the pediatric intensive care unit [7]. Pulmonary complications, both infectious and non-infectious, represent a particularly common and serious morbidity of HSCT, and thus, the topic is addressed in three separate articles. Other organ system dysfunction associated with HSCT that results in substantial morbidity and mortality including neurologic complications and acute kidney injury are also reviewed. Finally, in an attempt to provide appropriate balance, the ethics of caring for such a high-risk population are described and delineated.

With rejuvenated interest in the care of this highrisk patient population, it is hoped that further research will be initiated, improvements in outcome will continue and this potentially curative therapy will be made available to a wider spectrum of diseases and patients with greater propensity for success.

\section{References}

[1] Pasquini MC, Wang Z. Current use and outcome of hematopoietic stem cell transplantation: CIBMTR summary slides, 2013. Available at: http://www.cibmtr.org. Accessed August 27, 2014

[2] Chima RS, Daniels RC, Kim MO, Li D, Wheeler DS, Davies $\mathrm{SM}$, et al. Improved outcomes for stem cell transplant recipients requiring pediatric intensive care. Pediatr Crit Care Med 2012;13(6):e336-42.

[3] Tamburro RF, Barfield RC, Shaffer ML, Rajasekaran S, Woodard P, Morrison RR, et al. Changes in outcomes (1996-
2004) for pediatric oncology and hematopoietic stem cell transplant patients requiring invasive mechanical ventilation. Pediatr Crit Care Med 2008;9(3):270-7.

[4] Fiser RT, West NK, Bush AJ, Sillos EM, Schmidt JE, Tamburro RF. Outcome of severe sepsis in pediatric oncology patients. Pediatr Crit Care Med 2005;6(5):531-6.

[5] Kutko MC, Calarco MP, Flaherty MB, Helmrich RF, Ushay $\mathrm{HM}$, Pon S, et al. Mortality rates in pediatric septic shock with and without multiple organ system failure. Pediatr Crit Care Med 2003;4(3):333-7.

[6] Bojko T, Notterman DA, Greenwald BM, De Bruin WJ, Magid MS, Godwin T. Acute hypoxemic respiratory failure in children following bone marrow transplantation: An outcome and pathologic study. Crit Care Med 1995;23(4):755-9.

[7] Duncan CN, Lehmann LE, Cheifetz IM, Greathouse K, Haight AE, Hall MW, et al. Pediatric Acute Lung Injury and Sepsis (PALISI) Network. Clinical outcomes of children receiving intensive cardiopulmonary support during hematopoietic stem cell transplant. Pediatr Crit Care Med 2013;14(3):261-7.

[8] van Gestel JP, Bierings MB, Dauger S, Dalle JH, Pavlíček P, Sedláček P, et al. Outcome of invasive mechanical ventilation after pediatric allogeneic hematopoietic SCT: Results from a prospective, multicenter registry. Bone Marrow Transplant 2014;49(10):1287-92.

[9] van Gestel JP, Bollen CW, Bierings MB, Boelens JJ, Wulffraat NM, van Vught AJ. Survival in a recent cohort of mechanically ventilated pediatric allogeneic hematopoietic stem cell transplantation recipients. Biol Blood Marrow Transplant 2008;14(12):1385-93.

[10] Willson DF, Thomas NJ, Tamburro R, Truemper E, Truwit J, Conaway M, et al. Pediatric Acute Lung and Sepsis Investigators Network. Pediatric calfactant in acute respiratory distress syndrome trial. Pediatr Crit Care Med 2013;14(7):657-65.

[11] Willson DF, Thomas NJ, Markovitz BP, Bauman LA, DiCarlo JV, Pon S, et al. Pediatric Acute Lung Injury and Sepsis Investigators. Effect of exogenous surfactant (calfactant) in pediatric acute lung injury: A randomized controlled trial. JAMA 2005;293(4):470-6.

[12] Yanik GA, Grupp SA, Pulsipher MA, Levine JE, Schultz $\mathrm{KR}$, Wall DA, et al. TNF receptor inhibitor therapy for the treatment of children with idiopathic pneumonia syndrome (IPS). A joint Pediatric Blood and Marrow Transplant Consortium (PBMTC) and Children's Oncology Group (COG) study (ASCT0521). Biol Blood Marrow Transplant 2014;S10838791(14)00600-4

[13] Yanik GA, Horowitz MM, Weisdorf DJ, Logan BR, Ho VT, Soiffer RJ, et al. Randomized, double-blind, placebocontrolled trial of soluble tumor necrosis factor receptor: Enbrel (etanercept) for the treatment of idiopathic pneumonia syndrome after allogeneic stem cell transplantation: Blood and marrow transplant clinical trials network protocol. Biol Blood Marrow Transplant 2014;20(6):858-64.

[14] Morris SH, Haight AE, Kamat P, Fortenberry JD. Successful use of extracorporeal life support in a hematopoietic stem cell transplant patient with diffuse alveolar hemorrhage. Pediatr Crit Care Med 2010;11(1):e4-7.

[15] Di Nardo M, Locatelli F, Palmer K, Amodeo A, Lorusso $\mathrm{R}$, Belliato $\mathrm{M}$, et al. Extracorporeal membrane oxygenation in pediatric recipients of hematopoietic stem cell transplantation: An updated analysis of the Extracorporeal Life Support Organization experience. Intensive Care Med 2014;40(5):754-6. 